\title{
DISCOVERING OPPORTUNITIES IN THE SOLAR ENERGY INDUSTRY: A SUBJECTIVISTIC VIEW OF ENTREPRENEURIAL ACTIVITY
}

\author{
Gloria Cuevas-Rodriguez ${ }^{1}$--- Carmen Cabello-Medina ${ }^{2}$ \\ ${ }^{1,2}$ Department of Management and Business Administration, Pablo de Olavide University, Seville (Spain)
}

\begin{abstract}
Using the subjectivist view of entrepreneurship, the focus of this paper centers on understanding how certain individuals have created opportunities in the solar energy industry. An in-depth case study is developed to analyse the subjectivist character of discovery and creativity; the relevance of organizational learning for entrepreneurship; and the role of entrepreneurs' experiences in shaping a firm's subjective productive opportunity set. Through this research the relationships between the subjective visions and experiences of entrepreneurs, and perceived opportunities are presented. Besides the diversity of the problems that entrepreneurs encounter during the creation and development of the company, and the range of resources utilized are also discussed.
\end{abstract}

Keywords: Entrepreneurship, Business opportunities, Subjectivistic view, Organizational learning, Entrepreneur's experience.

Received: 9 September 2013/ Revised: 14 December 2013/ Accepted: 23 December 2013/ Published: 20 January 2014

\section{INTRODUCTION}

Opportunity has become a central concept in entrepreneurship research (Shane and Venkataraman, 2000; Eckhardt and Shane, 2003), which has shifted its attention from entrepreneurs and their behaviors toward the study of the role played by opportunities (Short et al., 2009). Opportunities are different ways to innovate in accordance with the five types identified by Shumpeter (1934) with the introduction of new products, introduction of new methods of production, opening of new markets, introductions of new materials or sources of supply; and developing new organizational structures. Nevertheless, the interest in opportunities goes beyond their conceptualization and tries to understand the nature, antecedents and outcomes of these opportunities. Among these issues, the discovery versus the creation of opportunities has drawn attention in entrepreneurship literature (Short et al., 2009). 
Two prominent schools of thought can be identified in terms of the way opportunities are found- search vs. discovery. The first holds that opportunities are identified through a purposeful, rational and systematic search process (Herron and Sapienza, 1992; Drucker, 1998) to give a response to a particular problem. Conversely, discovery sustains that opportunities are unknown until discovered and that one cannot deliberately search for something that one does not know exists (Kaish and Gilad, 1991; Kirzner, 1997). Opportunities emerge in the minds of specific individuals who generate them from their own cognitive resources and knowledge (Alvarez et al., 2005).

On the basis of this latter argument, the subjectivist theory of entrepreneurship (Mahoney and Michael, 2005; Kor et al., 2007) highlights the role of creativity, surprise and learning in this process of opportunity discovery. There are numerous possibilities for the creativity and autonomy of individual choice, and the entrepreneurs' subjective perceptions and personal knowledge can shape them.

Using this theoretical framework, and developing an in-depth case study, this research aims to analyze the subjective nature of entrepreneurial discovery and the creation of opportunities in the solar energy industry. With this in mind, the main statements of the subjectivist theory are analyzed: the subjectivist character of discovery and creativity, the significance of organizational learning for entrepreneurial activities and the role of entrepreneurs' experiences in shaping a firm's subjective productive opportunity set (Kor et al., 2007).

The case study, Strengthsun, is a successful Spanish firm which operates in the photovoltaic industry. Founded in 2005, the firm took advantage of the opportunities offered by a highly favorable environment: an activity with an undoubtedly social acceptance (renewable energy) and Spanish governmental regulation which encouraged its development. This paper demonstrates how Strengthsun was able to rapidly acquire highly valuable knowledge about how to manage their value chain effectively. Although there were no substantial entry barriers in this industry it was necessary to build capabilities to deal with the complex administrative procedures - to manage permits and licenses - and overcome the difficult financial conditions. Two key factors provided Strengthsun a great flexibility and dynamism at decision making - being a young, smallsized firm, and the distinctly entrepreneurial attitude of the founders. It has not only allowed them to react quickly and efficiently to changing market trends, but it has also made them an attractive partner for larger companies willing to go into the field.

Overall, the case of Strengthsun illustrates the importance of both human choices and the perceptions of entrepreneurs (highlighted by the subjectivist theory) in identifying, leveraging and creating resources, in order to achieve a competitive advantage.

\section{THEORETICAL BACKGROUND}

Entrepreneurs are considered innovators who turn information into potentially useful knowledge (Shumpeter, 1934) and absorb market details through an innate capacity to recognize opportunities. 
Subjectivist theory of entrepreneurship highlights the role of creativity, surprise and learning in the process of opportunity discovery (Mahoney and Michael, 2005; Kor et al., 2007) and emphasizes the non-deterministic, evolutionary nature of dynamic capabilities and entrepreneurial activities. Entrepreneurs are considered formulators of mental images or mental constructs in the process of conceiving new ventures and they not only respond to changes in the business environment, but also create change (Alvarez and Barney, 2005). That explains why it is important to understand entrepreneurs' thoughts and interpretations, as individuals can experience and change their environment through their own mental filters.

Although closely related, three main statements can be highlighted in the subjectivist theory of entrepreneurship. First, it stresses the subjectivist character of discovery and creativity. The subjective perceptions of entrepreneurs shape their own visions about the possible uses of a specific resource, as well as the possible combinations of resources, and the business opportunities resulting from such resources and combinations. So, even when operating with the same resources, different individuals may generate entirely different services from these resources (Penrose, 1959). These subjective perceptions result in multiple entrepreneurial choices and activities. To a certain extent, the entrepreneur's vision about the opportunities stems from his personal knowledge of the firm's unique bundle of resources and capabilities (Kor et al., 2007). Furthermore, knowledge is a flow concept rather than a given good. Therefore, the pattern of knowledge is continually changing through processes of organizational learning. Secondly, subjectivist theory of entrepreneurship also highlights the relationship between entrepreneurial creativity and organizational learning. Entrepreneurs influence an organization's learning by discovering, learning, creating and undertaking new entrepreneurial opportunities during interactions with an ever-changing and unpredictable business environment (Witt, 1998). Finally, entrepreneurs' subjective knowledge and intuition are strongly shaped by their experiences within the firm, the team, and the business environment (Kor et al., 2007). Entrepreneurs' personal knowledge is viewed as subjective, not only because different entrepreneurs produce different combinations of knowledge, but also due to the fact that these entrepreneurs interpret and act on these new combinations of knowledge in unique ways (Lachmann, 1986). The personal knowledge of entrepreneurs is experiential as different people will discover different things and have varying interpretations of the same experiences. Past experiences of entrepreneurs will influence their perceptions about viable alternatives and new business opportunities.

By examining these three statements of the subjectivist theory of entrepreneurship in the context of a real case, this paper highlights the subjective nature of entrepreneurial discovery and creativity of profit opportunities in the solar energy industry.

\section{EMPIRICAL RESEARCH: THE STRENGTHSUN CASE STUDY}

As the research question is concerned with the analysis of the main statements provided by subjectivist entrepreneurship theory, an in-depth case study was selected to understand the situation, processes, decisions taken, and the context (Merriam, 1998). 
The selected case is Strengthsun, a successful Spanish firm in the photovoltaic industry, with 30 employees and a turnover of 60 million euros in 2008. Founded in 2005, the firm took advantage of a highly favourable environment: an activity with an undoubtedly social acceptance (renewable energies) and Spanish governmental regulation which encouraged its development. However, three years later, the firm was able to respond to harsh new conditions suffered by the industry in Spain, during which time many companies disappeared. The firm demonstrated that the subjective entrepreneur's perceptions and experiences were key factors in continuing to create profitable opportunities. For both periods of time, subjectivist theory of entrepreneurship offers interesting explanations of the entrepreneurial activity in the solar energy industry.

Data collection included both primary and secondary sources. Firstly, by means of interviews and long conversations with three (of the four) founders. Researcher triangulation was used in interviews as they were conducted by two researchers who recorded, transcribed and checked them. Secondary data was obtained from the website and pertinent information files of the company (internal reports and economic and financial information). The data collected in this longitudinal study covers the period from 2005-2010. Furthermore, analysis of the photovoltaic regulatory framework was necessary to understand the main opportunities and challenges of the company during this period.

In the case study, three of the main statements provided by subjectivist entrepreneurship theory are analyzed. First, the inception of the company is examined, taking into account the importance of subjectivity in entrepreneurial discovery and creativity. Secondly, the role of organizational learning in entrepreneurial activities in Strengthsun is analysed, not only as a way to acquire knowledge about how to manage its core processes, but also to achieve the needed strategic renewal when the market conditions dramatically changed. Also, as a specific result of this organizational learning in Strengthsun, in-depth analysis of its geographical expansion was performed in order to understand how international opportunity discovery occurred. Finally, how both entrepreneur's industry-specific experiences and team-specific experiences were considered to understand how they shaped the subjective perceptions of Strengthsun's founders in a way that determined their key decisions and, consequently, the life of the company.

\section{THE CASE SETTING}

\subsection{The Firm and Regulatory Framework}

The photovoltaic industry has been an attractive option for entrepreneurs and investors. The objectives established in the Spanish Renewable Energy Plan 2005-2010 and the regulations which encouraged photovoltaic activity (generous premiums and tax benefits for environmental investments, among others) favoured the introduction of a great number of companies developing solar energy.

Apart from these general factors, Strengthsun's place of origin (Navarra, in the north of Spain) provided a particularly favourable social and political context in which to carry out this business project. In the late 90s, the government of the autonomous region of Navarra, pioneer in 
the area of wind power, looked for other ways of generating renewable energy. Thus, they focused on photovoltaic energy and this led to the creation of the company Aesol, the first company to build solar farms. Aesol was a subsidiary of Corporación de EnergíaHidroeléctrica de Navarra (EHN), a pioneer corporation in the development of wind energy in Spain, which was acquired by Acciona in 2005. During the first years of Aesol (2000-2005), the philosophy of solar farms was very different from the philosophy that finally prevailed in the photovoltaic industry. On the one hand, it aimed to further extend the business opportunities offered by solar energy to include the local community. In other words, those people sensitive to the environment could become co-owners of a photovoltaic energy installation by investing part of their savings in a project that was also very profitable (about $8 \%$ ). On the other hand, town councils provided access to some low productivity land, qualified as communal land, by designating them for the installation of solar farms. Thus, town councils could simultaneously reap political benefits by developing an initiative in the clean energy field, whilst filling the municipal coffers with the revenues from the activities developed on their land (building permits and other taxes).

As one would expect, a great number of companies emerged in such a favourable climate for the photovoltaic business, such as Strengthsun, willing to take advantage of the existing opportunities. However, in 2008, the Spanish Government admitted that growth of the photovoltaic solar power installed was much higher than expected (while the Renewable Energy Plan 2005-2010 aimed to connect 371 MW by the end of the decade, one year before the end of this term, the power installed already surpassed 3354 MW). They realized that excessive remuneration of this type of energy could increase electrical system costs and decided that the introduction of large installations should be rationalised in order to avoid their division into smaller installations. Thus, following some years of amazing growth in the photovoltaic field, the Spanish regulation RD 1578/2008 established quotas for the power installed, reduced tariffs and put an end to the possibility of creating collective farms. All this, reinforced by additional measures, brought the field to a standstill. The first effects of this new regulation were a drastic reduction in the number of new installations - from installing $2661 \mathrm{MW}$ in 2008 to a maximum of 500 MW in 2009 (Energías Renovables, 2009). Consequently, employment in the industry was affected, with: 20,000 jobs lostin the same period. All this meant that many companies disappeared.

Nevertheless, in this dramatic situation, especially for small companies, certain subjective entrepreneurs' perceptions and experiences could involve discovering profitable opportunities. Only big companies, or those companies which knew how to reposition their business (as was the case with Strengthsun), survived.

\subsection{The Subjectivist Character of Discovery and Creativity: Why was Strengthsun Born?}

Subjectivist entrepreneurial discovery occurs as entrepreneurs seek to seize the opportunities offered by certain market frictions. In these situations, entrepreneurs act as innovators who turn information into useful knowledge. Their interactions with customers, technologies and firms set 
the discovery procedurein motion that will be put to the market test and become entrepreneurial activities (Kor et al., 2007).

In the case of Strengthsun, both the national and regional photovoltaic markets were abound with opportunities. The national regulation clearly encouraged photovoltaic activity and the regional government also provided an extremely munificent social and political context.

Strengthsun was born in 2005, the result of an amalgamation between two small companies that operated in different fields: an engineering company and a consultancy whose field of expertise was local development. The founders of the two companies had very strong ties (they had been employees and colleagues in the same consultancy firm years ago), who used to share information and interests, both about business opportunities and the possibilities of working together again as a team. Only the creativity and imagination of entrepreneurs could shape the perceptions about common interests and opportunities in the photovoltaic activity. They perceived that the interests of both companies could converge in the photovoltaic activity. For the consultancy firm, which prepared development plans for towns, the construction of solar farms could potentially represent an interesting business proposition for their town council clients as a source for revenues and economic activity. For the engineering company, making photovoltaic installation projects could become a way of diversifying their business. Both companies, by means of this new venture, could complement their abilities: on the one hand, engineering knowledge to design the projects and, on the other hand, a wide network of contacts with town councils and other social agents provided by the consultancy specializing in local development.

It is interesting to highlight the subjectivism of knowledge, in the sense that each team member held different types of knowledge, and such knowledge and information needed to be interpreted with regards to their possible uses in practice (Foss et al., 2008). The composition and team dynamics of the entrepreneurial team are also relevant issues. That is, entrepreneurs individually may not have the complete set of skills and knowledge to meet a particular venture's needs. However, a team of entrepreneurs can bring together multiple perspectives and pool team members' knowledge, skills, and efforts to produce high-quality outcomes (Kor, 2003). Thus, the understanding of the subjectivist nature of opportunity discovery could be improved by considering the social and cognitive interactions among team members (Foss et al., 2008). This combination made the expansion and combinations of concepts possible, 'making visible what might (without them) have never been' (Baron, 2007).

\subsection{Organizational Learning in Entrepreneurial Activity: How Did Strengthsun Build Its Capabilities for Managing its Business Model? How They Could Respond to The New Environment?}

Subjectivist perspective of entrepreneurship emphasizes organizational learning as a collective phenomenon in which entrepreneurs exchange ideas and knowledge, create new economic opportunities, seek resources for developing these opportunities and achieve the 
strategic renewal of the enterprise, during interactions with an ever-changing an unpredictable business environment (Witt, 1998; Crossan et al., 1999; Kor et al., 2007).

From the analysis of the case, the relevance of organizational learning in Strengthsun was observed - not only to establish their business model and the set of activities in the value chain, but also to respond to new rules in the business environment.

\subsection{The Business Model}

Prior to the merger of the two companies that later formed Strengthsun, each carried out its area of expertise independently. However, they quickly learnt how the photovoltaic industry operated, so they took the following step and tried to cover a greater number of activities from the value chain of the sector. With this in mind they founded Strengthsun, which would design, promote, build and sell photovoltaic installations (ver Fig. 1).

This a complex process that involves many agents: several public administrations at local, regional and national level, electricity companies, financial institutions, small and large investors, suppliers and building companies, etc. As one of the founders remarked, the biggest difficulty in the photovoltaic business and our main expertise is knowing how to articulate the entire process efficiently. The process of organizational learning in Strengthsun allowed the company successfully to manage its value chain.

A brief description of the activities involved in the entire process of promoting and selling a photovoltaic installation can help us understand the complexity of their business:

1- Search for an appropriate site. For the installation of a solar farm, a plot of land must have a point where the power generated can be transferred to the network, and this point must be close enough so that it does not affect the profitability of the investment. The information concerning evacuation points becomes a key aspect when beginning a project. In practice, obtaining such information means depositing a substantial bank guarantee (half a million euros per MW) in favor of the electricity company.

The problem could become more complicated than a simple matter of proximity to the evacuation point. Due to the limited capacity of the electrical network in some areas to absorb the power generated, the electricity company cannot authorize the connection even though there is an evacuation point. Occasionally, it could be even necessary to reinforce a substation to absorb the power generated in several installations. In those cases, the promoters of the area must assume the cost of modernizing the substation.

2- Developing the project and managing the administrative requirements of the authorities and the electricity company. The duration of this phase of the project is completely in the hands of the administration (regional authorities assume control of the administrative issues relating to the environment and industry and town councils). In some Spanish autonomous regions permits and administration, technical and economic formalities can last up to one year, although these periods vary considerably from one region to another. 
3- In the photovoltaic business process, the sale to the end client isone the first phases. As soon as the company starts building the installation, it must be sold. The way in which investors are recruited has changed substantially since the beginning of Strengthsun. Initially, recruitment was characterized by a highly personalized approach to selling solar panels to private investors. The changes in Spanish regulations imposed restrictions on the sale of installations in portions and restricted the access to smaller investors. Strengthsun's final client is currently represented by big investors: private banks and investment funds (mainly from Switzerland and Germany), who not only rely on resources to invest, but who have also decided to bet on clean energy projects. A peculiar group of clients that has emerged comprises those companies that need green certification to compensate their $\mathrm{CO} 2$ emissions and who, regardless of their moral commitment to environmental matters, will become captive clients of renewable energies.

4- Once the project has completed all the steps, building of the park commences, which involves buying the material required (modules, investors, etc.), and the installation itself. Strengthsun acquires all the material needed from national suppliers located throughout Spain. A larger company could have employees specialized in finding and contacting foreign suppliers. However, for Strengthsun, as happens with other smaller companies, working with national suppliers means reducing the costs associated with the search for suppliers and the uncertainty associated with the negotiation process. To build the installation they subcontract local companies.

5- Strengthsun's link with the installation does not end with the construction and sale of the park. The investor"s (client"s) profitability is related to the good standing of the installation throughout its operating life (estimated at 25 years approximately). As a consequence, Strengthsun uses the maintenance of the installation to re-affirm the prestigious reputation it has gained for confidence and reliability. "We have never refused to solve a problem for a client, even if it represented a high cost. It marks the difference between us and many large companies."

6- Lastly, Strengthsun undertakes innovation projects to develop new elements and improve installation efficiency. Furthermore, it investigates the technology of other renewable energies that could represent an opportunity to diversify their business in the following years.

Due to fact that Strengthsun was start-up company, embracing this complex set of activities represented a great challenge for which organizational learning played a key role. Organizational learning is an essential aspect of subjectivist theory of entrepreneurship, in the sense that entrepreneurs can collectively discover, learn and create new entrepreneurial opportunities, as well as shape new images of innovative interpretive frameworks for handling new types of business problems (Witt, 1998; Kor et al., 2007). Then, it seems that in Strengthsun, the entrepreneur's managerial experiences within their prior industries (interactions with buyers, 
suppliers, and distributors in engineering activities), as well as their own entrepreneurial attitudes, made organizational learning possible and shaped their perceptions about the business model that the company would be able to develop in the industry. Embracing a great number of activities of the value chain, the company created new economic opportunities and sought resources to develop these activities.

In this sense, the lack of financial resources could have become an important obstacle for the growth of Strengthsun. As Kor et al. (2007) state, many viable new business ventures lack sufficient financial funds to make substantial capital investments that are essential for growth. Nevertheless, these new ventures have the organizational capability to attract the necessary financial support for these entrepreneurial ventures.

Indeed, one main difficulty at the beginning of Strengthsun was financing. It was not enough to have the qualifications required to design, promote, build and sell photovoltaic installations. The initial investment needed to begin the project was 32 million euros. "It really made us dizzy," says one of the founders. This was an important economic investment that required an appropriate level of resources.

At this point, the basic fact of why these entrepreneurs were successful in acquiring the resources they needed is related to certain behavioral and cognitive variables (Baron, 2007): entrepreneurs' social skills. That is to say, their ability to interact with others in an effective manner and to build social networks of personal relationships with others, which could help them to acquire the resources needed. In fact, Strengthsun managed to attract the necessary financial support. The introduction of two important local businessmen as partners provided the company not only with the money it needed, but also the legitimacy and reliability required by financial institutions and other agents in the field.

The response to the new rules in the photovoltaic sector: internationalization Organizational learning doesn't only produce discovering and creating of new economic opportunities but also allows the company to manage its strategic renewal Crossan et al. (1999) in an unpredictable business environment.

One of the most important difficulties that the firm had to cope with was in 2008, when the Spanish photovoltaic market came to a standstill. Following some years of amazing growth in the photovoltaic field, the Spanish regulation established quotas for the installed power, reduced tariffs and put an end to the possibility of creating collective farms, among other measures. The first effects of this new regulation were a drastic reduction of new installations and many companies disappeared after enjoying sizeable profits. Under this unfavourable context, Strengthsun entrepreneurs made their particular choice: "we had learnt to make things very well, why not continue to exploit the acquired knowledge and the expertise attained in other fields?'

In 2008, the Spanish market exceeded all expectations but in the rest of Europe the growth rate of the photovoltaic industry was very irregular; therefore, they decided to look for business opportunities in neighboring countries. Countries with low power level installations (and, consequently, with a high growth potential), with a high level of solar radiation and government 
measures supporting photovoltaic energy became interesting objectives in the short and medium term.

Italy was the immediate gamble, where Strengthsun already has two delegations and has started to build $200 \mathrm{MW}$.

So, Strengthsun followed a natural geographical expansion process: they started at a local level, expanded their activities to regional and national levels until they reached the international market, where they have recently begun operating. However, the international opportunity discovery did not occur simply through serendipitous encounters with new information from networks or referrals but involved interpreting possible matches between pre-existing means (resources, skills, new technologies) and new ends (international markets) in a problem solving process. As Chandra et al. (2009) suggest, amongst others, internationalization experiences are not pure luck in the sense that various conditions influence who can and cannot discover different types of opportunities and the kinds of opportunities that are potentially discoverable. Pure chance or luck is "where the finder has done nothing to generate the outcome ... unrelated to his efforts, actions, thoughts and purposes" (Kirzner, 1997). The Strengthsun'scase, as well as the cases of accidental exporters (Styles and Harcourt, 2001) and "unplanned" internationalization (Bell, 1995; McAuley, 1999; Crick and Spence, 2005), are examples of what may at first seem to be luck. However, this is not the case., They are examples of the role played by social networks, combined with the competencies and motivations of the company that drive the discovery of international market opportunities.

In this sense, the main drivers of the international opportunity recognition of Strengthsun were: (1) prior knowledge, (2) international network structure, and (3) entrepreneurial orientation.

First, entrepreneurs' prior knowledge could make the internationalization possible (Venkataraman, 1997; Shane and Venkataraman, 2000). Although Strengthsun had limited experiential knowledge in an international business context, the company had to compete with big industrial groups and powerful international companies in the energy field. Furthermore, specific circumstances meant that Strengthsun also worked for international clients. When regulations allowed selling individual panels to private clients as personal investments, their main group of clients was from the national scope. Later, when the new regulation forced the sale of entire solar parks, the investment was too costly for private investors so they had to offer them to larger investors, such as banks and investment funds. The market widened to an international level and required the company to rely on the collaboration of investment fund intermediary agents and direct contact with big international investors. Nevertheless, as well as this limited international experience, the company also lacked knowledge about government, institutional frameworks, rules, norms, and values.

Then, how could any company overcome scarce international experience and successfully enter in a new market? The second driver, suggested above, is the international network structure. It is defined as the set of social and business networks that the firm has abroad. It is 
also considered an important driver of internationalization. These networks provide the access to new and different types of information and ideas that would otherwise be encountered (Wilkinson and Young, 2005). Sometimes, these networks are the means of accessing and co-producing resources required to further develop and exploit entrepreneurial opportunities, or managing the risks and uncertainties involved (Wilkinson and Young, 2005). Thus, networks, contacts and collaboration agreements become essential drivers for the internationalization of companies without significant prior experience. The entrance of Strength sun in Italy required having a manager in this country who had knowledge of government, institutional frameworks, rules, norms and so on. An Italian manager was recruited by a local company on behalf of Strengthsun. Also, it was difficult for a small company, such as Strength sun, to carry out big projects in Italy on its own. For example, to develop this important type of projects, they had build installations hand in hand with big companies in order to guarantee the operation to the banks financing the project. "If we had enough resources to provide financial support to the operation, we would not need to go to those big corporations, because we have the necessary managerialt capacity to develop the project on our own. Although being a small company allows us to be very agile when developing our activities, it also creates some inconveniencies."

Third, innovativeness, autonomy, and proactiveness are also suggested as drivers of opportunity recognition in international markets (Chandra et al., 2009). These were all embedded in the organizational culture of Strengthsun. The youth of the company, as well as the age of their employees (the oldest person, who is the manager and founding partner of the company, is 37 years old at the time of writing this article) and the distinctly entrepreneurial attitude of their founders, created an environment which encouraged new ideas to help improve the business operation and search for new opportunities to guarantee business continuity and success. The entrance of Strengthsun into new geographical markets shows the essence of this culture of adapting to change. In this sense, starting business in Italy has been helped, at the same time, by the young age of Strengthsun employees who moved to that country, for whom the company expansion meant an important opportunity for training, promotion and personal development.

\subsection{Entrepreneurs, Experiences: How do Industry-Specific and Team-Specific Experiences Shape Subjective Entrepreneurial Perceptions?}

Subjective entrepreneurial knowledge and perception is shaped by both managerial experiences within a specific industry and team-specific experiences (Kor et al., 2007).

Industry-specific experience involves interactions with buyers, suppliers, distributors, and other stakeholders, which produce knowledge about the opportunities, threats, competitive conditions and governmental regulations that are unique to each industry (Kor, 2003). Furthermore, this experience can be useful for perception and evaluation of new entrepreneurial opportunities as many developments in technology, competitive, and regulatory conditions in an industry follow a path-dependent pattern (Arthur, 1994). 
Strengthsun has been described as the result of an interesting association of two companies, without previous experience in the photovoltaic industry, which were willing to complement their respective abilities, and take advantage of the opportunities provided by this promising sector. Nevertheless, although such within-industry experience was absent, the two companies used their own goodwill and capitalized on their particular experiences in different sectors by initiating a new business venture. So, the birth of Strengthsun, per se, as new venture is the result of experienced entrepreneurship in related industries. This is an important issue to highlight as the literature suggests that a strong industry orientation may be counterproductive when timely adaptations to change are essential (Chandler and Hanks, 1994). The management team could be entrenched in historical views of competitive dynamics and their perception and imagination of the new entrepreneurial opportunities could be truncated.

Team-specific experience involves the managers experiences in functioning together as a team. It includes discussions and debates on strategic decisions during which managers learn from each other (Kor et al., 2007). A pre-condition of this team-specific experience is an intimate familiarity among team members.

At the start of Strengthsun the entrepreneurs were able to add their respective and different experiences from their own firms, as well as their common team experiences, given that the beginning of these entrepreneurs preceeded the creation of their respective companies, when they belonged to the same consultancy company, working as a team. The lasting and close personal ties of the Strengthsun entrepreneurs facilitated open healthy conversations and debates about new strategic directions for their own and different business, as well as their potential business opportunities. The effect of such interactions among managers as a social process was high levels of positive affect of entrepreneurs. Positive affect has been also suggested as an important cognitive variable explaining the success of new ventures (Baron, 2008). It implies enthusiasm, entrepreneurs are more likely to be persuasive and it encourages helpful and cooperative actions, not only among co-founders, but with employees, venture capitalists, potential customers, and others. As Kor and Mahoney (2000) state, only when entrepreneurs develop some familiarity about each others' skills, strengths, weaknesses, and idiosyncratic habits, can they make the best use of the team's diversity of talent, ideas and perspectives.

During the first six months, the entrepreneurs did not leave their respective companies. They tried to combine their previous activities with this new project in the photovoltaic sector, so they hired a professional manager. However, it is not always easy for a new person arriving at a company to interiorize the business culture, assume the owners" view as his/her own and to respond to the expectations of the entrepreneurs, who were intensely motivated when developing the project. When the time arrived to move forward: the founders decided to work full time for Strengthsun.As one of them declares: "The owners have to be really involved in the business to make the project a success."

This clearly highlights the team-specific experience expounded in subjective entrepreneurial theory. Indeed, the entrepreneurs' team-specific experience built during a long time made them to 
be able to shape a common perception about the opportunities to take and the strategies to develop. A new manager could hardly reproduce such a personal view of the business.

The benefits of this team-specific experience allow the company to gain advantages over their competitors. Three of the company founders are responsible for managing the key aspects of the business (management, engineering direction and project maintenance). Any decision related to entering into new projects, potential alliances with certain partners or the conditions governing this type of agreement is made very quickly, and it is made by the company owners themselves, which means that they have a maximum degree of involvement. In large corporations, however, these decisions are normally submitted for approval by committees comprising the directors of the different departments of the company, with different degrees of involvement in the project. This can notably slow down the entire process. The quick decision making which characterizes Strengthsun places them in a clearly advantageous position in comparison with those large organizations.

\section{CONCLUSIONS AND DISCUSSION}

Using the subjectivist view of entrepreneurship, authors have addressed the issue of how certain individuals create opportunities within the context of a specific sector - in this case, the solar energy industry.

Subjectivist theory of entrepreneurship highlights elements of individual creativity, discovery, learning and subjective perceptions as sources of entrepreneurial activities. Entrepreneurship is conceived as a process in which success depends on intuition and the ability to seize opportunities, rather than a rational and systematic search process. Substantial possibilities exist, and the entrepreneurs' subjective perceptions will enable him/her to harness them.

Through an in-depth case study three of the main statements of the subjectivist theory are analyzed: the subjectivist character of discovery and creativity, the relevance of organizational learning in entrepreneurial activity and the role of the entrepreneur's experiences in shaping subjective perceptions about economics opportunities. For the purpose of this analysis, the focus has been put on two landmarks in the entrepreneurial story of Strengthsun: first, its foundation and, second, its response (three years later) to the new and tough market conditions in Spain. In both instances, subjectivist theory of entrepreneurship provided interesting arguments for understanding entrepreneurial activities in the photovoltaic industry.

Indeed, the inception of Strengthsun can be viewed as the result of a subjective process of discovery and creativity. The company brought together the interests and expectations of two small companies, operating in different fields (an engineering company and a consultancy expert in local development), which saw the opportunities in the photovoltaic industry. Only the creativity and imagination of entrepreneurs could shape the perceptions about common interests and opportunities of these companies in the photovoltaic activity. 
Organizational learning has represented a key process in Strengthsun, not only to establish their business model and the set of activities in the value chain, but also to respond to new rules in the business environment. Strengthsun's value chain is a complex process which involves many agents (several public administrations, electricity companies, financial institutions, small and large investors, suppliers and building companies and so on) and articulating the entire process efficiently has become the biggest difficult in the photovoltaic business. The ability to manage such a complex process has been one of the key competences of the company on which it has based its competitive advantage. In this sense, organizational learning provided Strengthsun with highly valuable knowledge about how to manage their value chain effectively. Furthermore, when the Spanish photovoltaic market stopped growing, the entrepreneurs decided to continue exploiting the knowledge acquired and the expertise attained in other fields. As such the discovery of international opportunities has represented a particular case of organizational learning for strategic renewal in Strengthsun (exploring and learning new ways while exploiting what the entrepreneurs had learned). Therefore, the firm's entrepreneurial growth process involved at least two major forms of heterogeneity (Penrose, 1959). First, Strengthsun differed from one another in the resources it possessed, as the firm had the knowledge and skills to manage the whole value chain (resource heterogeneity). The second form of heterogeneity refers to how the entrepreneurs perceived a unique strategic opportunity in the use of such resources, given the entrepreneur's idiosyncratic information concerning how it may be productively deployed with the remainder of the firm's assets (heterogeneity of productive services from resources).

Finally, Strengthsun entrepreneurs' experiences, both industry-specific and team-specific, shaped their subjective entrepreneurial perceptions. Although one could argue that, strictlyspeaking, they lacked industry-specific experience, the two companies used goodwill and were able to capitalize on their particular experiences in different sectors by initiating a new business venture together. Their team-specific experience, which has been reinforced by lasting and close personal ties, encouraged them to share open conversations and debates about new strategic directions for the business as well as their potential business opportunities. Furthermore, the experiential knowledge of the skills, cognitive diversity, and habits of each team member were needed for the new firm's success. Equally important was the shared team-specific experience to facilitate group experimentation, cooperation, and learning. The results show how a high degree of diversity combined with the shared experience can improve the team creativity and entrepreneurial process

Overall, the case of Strengthsun illustrates the importance of both human choices and the perceptions of entrepreneurs (highlighted by the subjectivist theory) in identifying, leveraging and creating resources, in order to achieve a competitive advantage.

Funding : This work was supported by the Spanish Ministry of Science and Technology [ECO20 10-2 1859] Competing Interests: The authors declare that they have no conflict of interests.

Contributors/Acknowledgement: All authors contributed equally to the conception and design of the study. 


\section{REFERENCES}

Alvarez, S.A., R. Agarwal and O. Sorenson, 2005. Handbook of entrepreneurship research: Disciplinary perspectives. New York: Springer.

Alvarez, S.A. and J. Barney, 2005. How entrepreneurs organize firms under conditions of uncertainty. Journal of Management, $31(5):$ 776-793.

Arthur, W.B., 1994. Increasing returns and path dependence in the economy. Ann Arbor, MI: University of Michigan Press.

Baron, R.A., 2007. Behavioral and cognitive factors in entrepreneurship: Entrepreneurs as the active element in new venture creation. Strategic Entrepreneurship Journal, 1(1-2): 167-182.

Baron, R.A., 2008. The role of affect in the entrepreneurial process. Academy of Management Review, 33(2): 328-340.

Bell, J., 1995. The internationalization of small computer software firms: A further challenge to stage theories. European Journal of Marketing, 29(8): 60-75.

Chandler, G.N. and S.H. Hanks, 1994. Market attractiveness, resource-based capabilities, venture strategies ad venture performance. Journal of Business Venturing, 9(4): 331-350.

Chandra, Y., C. Styles and I. Wilkinson, 2009. The recognition of first time international entrepreneurial opportunities. International Marketing Review, 26(1): 30-61.

Crick, D. and M. Spence, 2005. The internationalization of high performing UK high-tech SMEs: A study of planned and unplanned strategies. International Business Review, 14(2): 167-185.

Crossan, M.M., H.W. Lane and R.E. White, 1999. An organizational learning framework: From intuition to institution. Academy of Management Review 24(3): 522-537.

Drucker, P.F., 1998. The discipline of innovation. Harvard Business Review, Nov-Dec: 149-157.

Eckhardt, J.T. and S.A. Shane, 2003. Opportunities and entrepreneurship. Journal of Management, 29(3): 333-349.

Energías Renovables, 2009. Available from http://www.energias-renovables.com/articulo/asif-pide-algobierno-que-legisle-para.

Foss, N.J., P.G. Klein, Y.Y. Kor and J.T. Mahoney, 2008. Entrepreneurship, subjectivism, and the resourcebased view: Toward a new synthesis. Strategic Entrepreneurship Journal, 2(1): 73-94.

Herron, L. and H. Sapienza, 1992. The entrepreneur and the initiation of new venture launch activities. Entrepreneurship Theory \& Practice, 17(1): 49-55.

Kaish, S. and B.B. Gilad, 1991. Characteristics of opportunities search of entrepreneurs versus executives: Sources, interests, and general alertness. Journal of Business Venturing, 6(1): 45-61.

Kirzner, I.M., 1997. Entrepreneurial discovery and the competitive market process: An Austrian approach. Journal of Economic Literature, 35(1): 60-85.

Kor, Y.Y., 2003. Experience-based top management team competence and sustained growth. Organization Science, 3(3): 383-397.

Kor, Y.Y. and J.T. Mahoney, 2000. Penrose's resource-based approach: The process and product of research creativity. Journal of Management Studies, 37(1): 109-139. 
Kor, Y.Y., J.T. Mahoney and S.C. Michael, 2007. Resources, capabilities and entrepreneurial perceptions. Journal of Management Studies, 44(7): 1187-1212.

Lachmann, L.M., 1986. The market as an economic process. Oxford: Blackwell.

Mahoney, J.T. and S.C. Michael, 2005. A subjectivist theory of entrepreneurship. In Alvarez, S A, Agarwal, R., \& Sorenson, O. (Eds.), Handbook o Entrepreneurship. Boston, MA: Kluwer. pp: 33-53.

McAuley, A., 1999. Entrepreneurial instant exporters in the scottish arts and crafts sector. Journal of International Marketing, 7(4): 67-82.

Merriam, S.B., 1998. Qualitative research and case study applications in education (Rev. Ed.). San Francisco, CA: Jossey-Bass.

Penrose, E.T., 1959. The theory of the growth of the firm. New York: John Wiley \& Sons.

Shane, S. and S. Venkataraman, 2000. The promise o entrepreneurship as a field o research. Academy of Management Review, 25(1): 217-226.

Short, J., D. Ketchen, C. Shook and D. Ireland, 2009. The concept of opportunity in entrepreneurial research: Past accomplishments and future challenges. Journal of Management, 36(1): 40-65.

Shumpeter, J.A., 1934. The theory of economic development. Cambridge, MA: Harvard University Press.

Styles, C. and T. Harcourt, 2001. Accidental exporters. Financial Review (April): 60-61.

Venkataraman, S., 1997. The distinctive domain of entrepreurship research: and editor's perspective in Katz J, Brockhaus R (Eds), Advances in entrepreneurship. Greenwich, CT: JAI Press. 3: 119-138.

Wilkinson, I.F. and L.C. Young, 2005. Toward a normative theory of normative marketing theory. Marketing Theory, 5(4): 363-396.

Witt, U., 1998. Imagination and leadership: The neglected dimension of an evolutionary theory of the firm. Journal of Economic Behavior and Organization, 35(2): 161-177.

Views and opinions expressed in this article are the views and opinions of the author()s, International Journal of Management and Sustainability shall not be responsible or answerable for any loss, damage or liability etc. caused in relation to/arising out of the use of the content. 